\title{
Experimental Assessment of the Sprinkler Application Rate for Steep Sloping Fields
}

\author{
F. E. Cisneros Espinosa ${ }^{1}$; P. Torres ${ }^{2}$; and J. Feyen ${ }^{3}$
}

\begin{abstract}
The Programa para el Manejo del Agua y del Suelo (PROMAS) assists the local farming community in introducing new types of locally available irrigation equipment that are both inexpensive and water efficient. Field experiments enabled determining the maximum application rates that cause zero runoff for slopes above $16 \%$ for low-cost sprinkler systems.
\end{abstract}

DOI: 10.1061/(ASCE)0733-9437(2007)133:3(276)

CE Database subject headings: Sprinkler irrigation; Slopes; Runoff; Experimentation.

\section{Introduction}

To help subsistence farmers in the dry valleys of the Austro Ecuatoriano (the southern Ecuadorian Andes region between $2^{\circ} 15^{\prime}$ and $3^{\circ} 30^{\prime}$ south) produce surpluses so the community can begin the path to economic growth, PROMAS has been experimenting with the introduction of low-cost sprinkler systems, with an investment cost of less than 250 U.S. dollars per hectare, to replace the labor-intensive and wasteful contour, hand or animal power made, furrow systems. From pilot plots it became clear that a key element for achieving acceptable levels of irrigation efficiency and uniformity was the selection of the sprinkler/nozzle combination. Field experiments, using locally available sprinkler equipment, were conducted to define the setup (sprinkler pattern, sprinkler spacing, and operation pressure) resulting in the maximum allowable application rate for different soil types and field slopes. The results enabled expanding the indicative table for sprinkler rate, published by Keller and Bliesner (1990), for field slopes larger than $16 \%$.

\section{Material and Methods}

A portable irrigation system was designed. Variation in application rate was achieved by varying the spacing between the sprin-

\footnotetext{
${ }^{1}$ Director, Programa para el Manejo del Aguay del Suelo (ROMAS), Univ. de Cuenca, Casilla 01-01-168, Campus Universitario Av. 12 de Abril s/n, Cuenca, Ecuador. E-mail: fcisnero@ucuenca.edu.ec

${ }^{2}$ Junior Researcher, Programa para el Manejo del Agua y del Suelo (ROMAS), Univ. de Cuenca, Casilla 01-01-168, Campus Universitario Av. 12 de Abril s/n, Cuenca, Ecuador. E-mail: ptorres@ucuenca.edu.ec

${ }^{3}$ Professor, Division Soil and Water, Dept. of Land Management and Economics, Faculty of Bioscience Engineering, Katholieke Univ. Leuven, Celestijnenlaan 200 E, B-3001 Heverlee, Belgium. E-mail: jan.feyen@ biw.kuleuven.be

Note. Discussion open until November 1, 2007. Separate discussions must be submitted for individual papers. To extend the closing date by one month, a written request must be filed with the ASCE Managing Editor. The manuscript for this technical note was submitted for review and possible publication on January 13, 2004; approved on August 28, 2006. This technical note is part of the Journal of Irrigation and Drainage Engineering, Vol. 133, No. 3, June 1, 2007. CASCE, ISSN 07339437/2007/3-276-278/\$25.00.
}

klers on the lateral and between the laterals, and by adjusting the operating pressure. The sprinkler used in the experiments was a NAAN sprinkler, Type 435, with 4-mm-diameter nozzle, operating within a pressure range of $150-400 \mathrm{kPa}$, with a flow rate of $0.35-0.63 \mathrm{~m}^{3} \mathrm{~h}^{-1}$ and radius of coverage of $23-25 \mathrm{~m}$. The application rates realized with the system varied between 1.80 and $32 \mathrm{~mm} \mathrm{~h}^{-1}$.

The water source was a nearby river or reservoir. A filter and flow control device removed the sediments and controlled the flow in the mainline. When the pressure by gravity was too small, a movable pump unit was used to generate enough pressure. The characteristics of the pump unit were: $Q=22.2 \mathrm{~m}^{3} \mathrm{~h}^{-1}$, $H=350 \mathrm{kPa}, P=0.30 \mathrm{KW}$, and a $5 \mathrm{~cm}$ diameter intake pipe. On each plot four laterals, with four equally spaced sprinklers per lateral, were installed (see Fig. 1).

The sprinklers were mounted on a riser pipe of $13 \mathrm{~mm}$ diameter and length of $0.60 \mathrm{~m}$. A manometer on each riser pipe was used to monitor the pressure at the inlet of the sprinkler during the experiment. Irrigation depth and distribution uniformity were determined using $15 \mathrm{~cm}$ diameter and $20 \mathrm{~cm}$ deep catch cans, placed in a $2 \mathrm{~m}$ grid. The sprinkler was positioned at the intersection of the diagonals of a $2 \times 2 \mathrm{~m}$ grid. The precipitation rate was

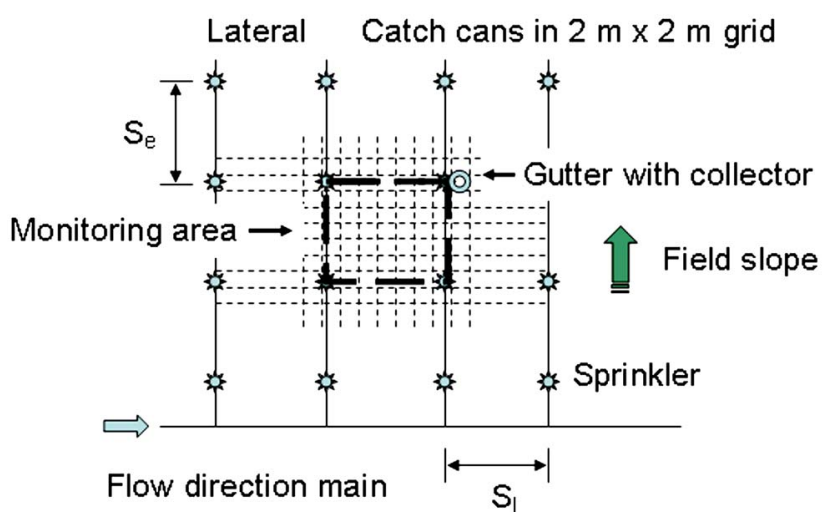

Fig. 1. Experimental setup with lateral pattern, the location of the sprinklers, catch cans, and gutter with collector at the downslope side of the monitoring area bounded by four sprinklers 
Table 1. Maximum Allowable Sprinkler Rate, Christiansen's Uniformity Coefficient, and the Distribution Uniformity as a Function of Sprinkler Setup and Field Slope, Measured on Four Sites in the Community of Tarqui on Clay Soil

\begin{tabular}{|c|c|c|c|c|}
\hline \multirow{2}{*}{$\begin{array}{l}\text { Field } \\
\text { slope } \\
(\%)\end{array}$} & \multirow[b]{2}{*}{ Sprinkler performance } & \multicolumn{3}{|c|}{ Sprinkler pattern } \\
\hline & & $9 \times 9 \mathrm{~m}$ & $9 \times 12 \mathrm{~m}$ & $12 \times 12 \mathrm{~m}$ \\
\hline \multirow[t]{3}{*}{0} & Maximum allowable application rate $\left(\mathrm{mm} \mathrm{h}^{-1}\right)$ & 4.42 & 1.80 & 3.22 \\
\hline & Christiansen's uniformity coefficient $(\%)$ & 76 & 71 & 80 \\
\hline & Distribution uniformity $(\%)$ & 68 & 58 & 66 \\
\hline \multirow[t]{3}{*}{16} & Maximum allowable application rate $\left(\mathrm{mm} \mathrm{h}^{-1}\right)$ & 3.22 & 1.80 & 1.81 \\
\hline & Christiansen's uniformity coefficient (\%) & 80 & 71 & 77 \\
\hline & Distribution uniformity $(\%)$ & 66 & 58 & 62 \\
\hline \multirow[t]{3}{*}{18} & Maximum allowable application rate $\left(\mathrm{mm} \mathrm{h}^{-1}\right)$ & 3.19 & 2.39 & 1.54 \\
\hline & Christiansen's uniformity coefficient (\%) & 80 & 67 & 57 \\
\hline & Distribution uniformity $(\%)$ & 70 & 58 & 43 \\
\hline \multirow[t]{3}{*}{28} & Maximum allowable application rate $\left(\mathrm{mm} \mathrm{h}^{-1}\right)$ & 3.65 & 4.87 & 2.74 \\
\hline & Christiansen's uniformity coefficient (\%) & 81 & 86 & 81 \\
\hline & Distribution uniformity $(\%)$ & 71 & 80 & 71 \\
\hline
\end{tabular}

defined according to Keller and Bliesner (1990), the distribution uniformity using the uniformity coefficient of Christiansen (1942) (UCC), and the distribution uniformity (DU) coefficient of Merriam et al. (1980). Experiments were run for 90-120 min under calm wind conditions and after saturation of the top $20 \mathrm{~cm}$ of the soil profile. Runoff was collected at the bottom of the plot with a covered $150 \mathrm{~mm}$ wide gutter.

A total of 38 experiments were conducted, of which 14 were on clay, 10 on sandy clay, and 14 on sandy soils. The slope of the fields ranged from 0 to $30 \%$. The basic infiltration rate was determined using a double-ring infiltrometer. The first sprinkler application rate applied was 5-10 times the basic infiltration rate. In subsequent runs the application rate was gradually decreased until no runoff was observed. The application rate resulting in zero runoff was defined as the maximum allowable application rate.

Table 2. Experimental Defined Maximum Allowable Application Rate $\left(\right.$ in $\mathrm{mm} \mathrm{h}^{-1}$ ) as a Function of Field Slope and Soil Type

\begin{tabular}{|c|c|c|c|c|c|}
\hline \multicolumn{2}{|c|}{ Clay soil } & \multicolumn{2}{|c|}{ Sand clay soil } & \multicolumn{2}{|c|}{ Sandy soil } \\
\hline Slope & $\begin{array}{c}I \\
\left(\mathrm{~mm} \mathrm{~h}^{-1}\right)\end{array}$ & Slope & $\begin{array}{c}I \\
\left(\mathrm{~mm} \mathrm{~h}^{-1}\right)\end{array}$ & Slope & $\begin{array}{c}I \\
\left(\mathrm{~mm} \mathrm{~h}^{-1}\right)\end{array}$ \\
\hline 0 & 4.80 & 0 & 18.91 & 0 & 27.52 \\
\hline 5 & 3.30 & 6 & 17.63 & 2 & 19.48 \\
\hline 8 & 4.86 & 11 & 10.24 & 4 & 12.80 \\
\hline 14 & 2.63 & 17 & 9.65 & 5 & 15.00 \\
\hline 16 & 2.93 & 20 & 8.10 & 9 & 10.40 \\
\hline 17 & 2.76 & 24 & 7.41 & 10 & 12.70 \\
\hline 18 & 2.70 & 26 & 5.01 & 12 & 11.90 \\
\hline 19 & 3.31 & 28 & 3.27 & 16 & 11.30 \\
\hline 20 & 2.80 & 29 & 3.49 & 16 & 9.44 \\
\hline 22 & 3.17 & 30 & 3.05 & 18 & 9.82 \\
\hline 24 & 2.56 & - & - & 22 & 8.43 \\
\hline 26 & 2.23 & - & - & 24 & 10.30 \\
\hline 28 & 1.42 & - & - & 25 & 8.83 \\
\hline 28 & 1.92 & - & - & 28 & 8.88 \\
\hline
\end{tabular}

\section{Results and Discussion}

Table 1 gives a summary of the experiments conducted in the community of Tarqui on fields with clay soil and average slopes of $0,16,18$, and $28 \%$. Table 1 depicts, for each field slope, the application rate that did not cause runoff. The UCC varied between 57 and $86 \%$, while the DU was between 43 and $80 \%$. The standard deviation of the measured UCC and DU was of the order of $12-18 \%$, corresponding to the standard deviation for hand move sprinklers in Merriam and Freeman (2002). The data in Table 2 reveal that for all soils the maximum allowable application rate decreases as the field slope increases. For the clay soils, the variation in maximum allowable application rate over the range of field slopes is smaller than for the sandy and sandy clay soils. For the sandy soils the maximum allowable application rate decreases approximately uniformly with increasing field slope. On the sandy clay plots a rather sharp drop in maximum allowable application rate was observed in the field slope range of 0-5\%. Between 5 and $30 \%$ field slope, the relationship between the maximum allowable application rate and field slope decreased on average with $0.422 \mathrm{~mm} \mathrm{~h}^{-1}$ per $1 \%$ increase of field slope.

Using step-wise regression analysis a relationship was derived between the ratio of the maximum allowable application rate $\left[I,\left(\mathrm{~mm} \mathrm{~h}^{-1}\right)\right]$ and the basic infiltration rate $\left[I_{b}\left(\mathrm{~mm} \mathrm{~h}^{-1}\right)\right]$, and the field slope $[X,(\%)]$. The regressions with the highest coefficient of determination are presented in Table 3. The regressions are of the semilogarithmic form with $R^{2}$ equal to $0.7412,0.9363$, and 0.8315 for clay, sandy clay, and sandy soils, respectively. These

Table 3. Relationship between the Ratio of the Maximum Allowable Infiltration Rate $\left[I\left(\mathrm{~mm} \mathrm{~h}^{-1}\right)\right]$ and the Basic Infiltration Rate $\left[I_{b}\left(\mathrm{~mm} \mathrm{~h}^{-1}\right)\right]$, and the Field Slope $[X(\%)]$ for Clay, Sand Clay, and Sandy Soils

\begin{tabular}{lcc}
\hline Soil type & Regression equation & $\begin{array}{c}\text { Coefficient } \\
\text { of determination } \\
\left(R^{2}\right)\end{array}$ \\
\hline Clay soil & $I / I_{b}=-0.4188 \ln (X)+1.8139$ & 0.7412 \\
Sand clay soil & $I / I_{b}=-0.4433 \ln (X)+1.7067$ & 0.9363 \\
Sandy soil & $I / I_{b}=-0.1254 \ln (X)+0.7259$ & 0.8315
\end{tabular}


Table 4. Indicative Maximum Application Rate as a Function of Soil Type and Field

\begin{tabular}{|c|c|c|c|c|c|c|c|c|}
\hline Slope (\%) & $0-5$ & $5-8$ & 8-12 & $12-16$ & $16-20$ & 20-24 & $24-28$ & 30 \\
\hline Soil texture and profile & \multicolumn{8}{|c|}{ Maximum application rate $\left(\mathrm{mm} \mathrm{hr}^{-1}\right)$} \\
\hline Coarse sandy soil to $1.8 \mathrm{~m}$ & 50 & 38 & 25 & 13 & 10 & 9.6 & 9.4 & 8.9 \\
\hline $\begin{array}{l}\text { Coarse sandy soil over more } \\
\text { compact soils }\end{array}$ & 38 & 25 & 19 & 10 & $\underline{9.6}$ & $\underline{9.4}$ & $\underline{8.9}$ & 5.2 \\
\hline Light sandy loams to $1.8 \mathrm{~m}$ & 25 & 20 & 15 & 10 & $\underline{8.9}$ & $\underline{7.4}$ & $\underline{5.2}$ & $\underline{3.3}$ \\
\hline $\begin{array}{l}\text { Light sandy loams over more } \\
\text { compact soils }\end{array}$ & 19 & 13 & 10 & 8 & 7.4 & 5.2 & 3.3 & 1.4 \\
\hline Silt loam to $1.8 \mathrm{~m}$ & 13 & 10 & 8 & 5 & 3.3 & 1.5 & 1.4 & 1.2 \\
\hline $\begin{array}{l}\text { Silt loam over more compact } \\
\text { soils }\end{array}$ & 8 & 6 & 4 & 2.5 & $\underline{1.5}$ & $\underline{104}$ & $\underline{1.2}$ & $\underline{0.4}$ \\
\hline $\begin{array}{l}\text { Heavy textured clays or clay } \\
\text { loams }\end{array}$ & 4 & 2.5 & 2 & 1.5 & 1.4 & 1.2 & 0.4 & 0.2 \\
\hline
\end{tabular}

data were used to expand the indicative values given by Keller and Bliesner (1990) for the maximum allowable sprinkler rates versus soil type and field slope, as depicted in Table 4 . Table 4 includes indicative values for the maximum allowable sprinkler rate for field slopes between 16 and 30\%. The application rates in bold, italic, and underlined are values derived from the field experiments. The other data were derived through extrapolation. It is evident that the maximum allowable application rates, as given in Table 4, for field slopes larger than $16 \%$ are subject to errors associated with the local field, and experimental and monitoring conditions, and therefore, those data should be used with care. In addition, maximum allowable application rates less than $3 \mathrm{~mm} \mathrm{~h}^{-1}$ are not very practical and difficult to implement with the available hardware. Furthermore, for those low application rates, wind strongly affects UCC and DU. For this reason values less than $3 \mathrm{~mm} \mathrm{~h}^{-1}$ for slopes larger than $16 \%$ are depicted in the light-gray shaded cells, at the left bottom of Table 4 .

\section{Conclusions}

The experiments presented in this paper were conducted with the objective of identifying the maximum sprinkler application rate that does not cause runoff on fields with slope between 16 and $30 \%$. Although one single sprinkler/nozzle was used, it was possible to adjust the sprinkler configuration and the operation pressure to apply rates from as low as 1 up to $30 \mathrm{~mm} \mathrm{~h}^{-1}$, and to define for different combinations of slope and soil type the maximum allowable sprinkler rate. Keller and Bliesner's (1990) table with maximum application rates was expanded with indicative application rates for field slopes larger than $16 \%$. The increasing rate with which the indigenous farmers in the Austro Ecuatoriano replace their furrow irrigation system with a portable low-cost sprinkler system underlines the economic attractivity of the switch in irrigation technology.

\section{Acknowledgments}

The writers would like to acknowledge Fundación para la Ciencia y la Tecnología, Ecuador for financial support and the farmers for their assistance with the field tests.

\section{References}

Christiansen, J. E. (1942). "Irrigation by sprinkling." Bulletin 67D, California Agricultural Experimental Station, Univ. of California at Berkeley, Berkeley, Calif.

Keller, J., and Bliesner, R. (1990). Sprinkle and trickle irrigation, Van Nostrand Reinhold, New York.

Merriam, J. L., and Freeman, B. J. (2002). "Irrigation water supplies to not inhibit improved water management." Proc., 18th Int. Congress on Irrigation and Drainage (ICID), ICID, New Delhi, India, 1-16.

Merriam, J. L., Shearer, M. N., and Burt, C. M. (1980). "Evaluating irrigation systems and practices." ASAE Monograph No. 3, Chap. 17, M. E. Jensen, ed., American Society of Agricultural Engineers, St. Joseph, Mich. 